\title{
微分値の局所的な分布に基づいた エッジ検出アルゴリズム
}

\author{
高 橋 禎 郎 $^{+*}$, 正会員 高 木 幹 雄 $^{\dagger}$

\section{An Edge Detection Algorithm Based on the Local Distribution of the Gradient}

\author{
Sadao Takahashi ${ }^{\dagger}$ and Mikio Takagi $^{\dagger}$
}

\begin{abstract}
In computer vision, we need the significant edges that are boundaries between different surfaces, or an object and its background.

In this paper, we propose a method for detecting significant edges based on the local distribution of gradient magnitude values. The analysis enables us to tell whether any significant edges exist locally. In the edge area, the distribution of gradient magnitude values can apparently be separated into two clusters. In the non edge areas, the distribution seems to be one cluster. The significant edges in the edge area are detected by an automatic thresholding technique after which line thining takes place. Since the method does not use any smoothing criteria, detected edges are located where we desire. The experiments show that significant edges are detected and textural edges are suppressed.
\end{abstract}

\section{1. まえがき}

エッジや線は画像特徵のひとつであるが, 画像処理 やコンピュータビジョンに扔いて, 最も重要な特徴の ひとつであり，それらの検出は基本的かつ重要なテー マのひとつである.特に, コンピュータビジョンにお いて, シーンを記述するためには画像内の輪郭を抽出 することが必要不可欠である11. シーン記述のために は, 物体を構成する輪郭を, 位置を正確に, 途切れが なく連続であり，さらに幅を薄く抽出する必要があ り,テクスチャなどの影響によるノイズはシーン記述 には不要なものである.

したがって，物体と物体，物体と背景といった境界
部分のエッジを抽出し, テクスチャなどの影響による ノイズを極力取り除くことがエッジ検出における重要 な課題である。本論文に扔けるエッジ検出には次の 3 つの目的が挙げられる.

（1） ある程度連続的で一定の方向であるような濃 度の不連続性（重要なエッジ）を検出すること.

（2）必要のない詳細（テクスチャによるノイズな ど)を抑圧すること.

（3）エッジの位置の正確さを保存すること.

画像のノイズ成分を取り除くために，局所的に平均 を求めたり，平滑化を行ったりしているものが多 (2)3). Canny ${ }^{4)}$ やこれらの方法では, ノイズ成分は取 り除くことができるが, 平滑化を伴うために, 微分画

キーワード：エッジ検出，輪郭，コンピュータビジョン，闎值処理，微分

1991 年 5 月 1 日受付

† 東京大学 生産技術研究所（广 106 東京都港区六本木 7-22-1, TEL 03-3402-6231）

* 現在, 株式会社リコーに勤務

$\dagger$ Institute of Industrial Science, University of Tokyo (7-22-1, Roppongi, Minato-ku, Tokyo 106, Japan) 
像の極大値の画素が平滑化を行わない場合とは一致し なくなることがあり，エッジの正確な位置が検出でき なくなることがある. Deriche $\mathrm{f}^{5)}$ は，ガウス関数の差 分をとる, DOG(Difference Of Gaussian) 関数を用い たエッジ検出手法を提案した。この手法は途切れのな い連続的なエッジを検出することが可能であるが，ガ ウス関数によって画像がぼかされるために，エッジの 正確な位置を決定することが問題となっている. Bergholm ${ }^{6}$ はガウス関数のパラメータを変化させて, 異なるレベルに画像をぼかし, 最もぼかした画像で重 要なエッジを検出したのち, エッジの位置をレベルの 異なる画像間で追跡して正確なエッジの位置を決定し ようとした。しかしながら，テクスチャによるノイズ を充分に抑えているとはいい難い。

本論文では，微分画像中の局所的な值の分布が，い わゆる重要なエッジが存在する部分と存在しない部分 とに違いがみられることを利用して, エッジの存在す る部分に対してのみ適応的な閾值処理を行うことによ りエッジを検出する手法を提案する．まず，エッジの 位置の正確さを保存することを重要と考え, 濃淡画像 をノイズの影響を受けにくい Sobel Operatorを用い て微分する．次に微分した画像を小ブロックに分割 し, 各ブロックの微分值の統計的特徴より, エッジの 存在する部分と存在しない部分とに分類する.エッジ の存在する部分に対して微分值を閾值処理し, エッジ である確率の高い要素を抽出した後, 極大值以外の値
を抑圧する細線化を施す．

本手法はエッジの統計的特徵を利用し，適応的な閾 值処理を行うため, 単一閾値では検出できないような 強度の弱いエッジを検出することができる．また，全 画像を適応的に閾值処理する場合には, テクスチャ部 分のノイズなどが検出されるのに対し, 本手法はエッ ジの存在する部分に対してのみ適応的な閾值処理を行 うため, テクスチャ部分のノイズなどがほとんど検出 されない.この点で本手法は優れている.さらに, 濃 淡画像の平滑化を行った後に微分を行うならば, 濃淡 画像を平滑化しないで微分を行った場合と比較して, 微分值の極大值の位置が異なることがあるため, エッ ジの位置の正確さが失われる. 本手法では画像の平滑 化を行わないので, 検出されるエッジの位置は正確で あるという点でも優れている.

本手法は, 画像解析の前処理としてのエッジの検 出, すなわち, 物体と物体, 物体と背景との間の, あ る程度連続的で一定の方向を持つ重要な濃度の変化の 極大值（エッジ）を検出することが目的である．本手 法による結果は, 例えばエッジ追跡》に適用され,さ らに多角形近似などの高レベル処理に適用される。

\section{2. 微分画像における画素值の分布}

エッジは濃淡画像の輝度の変化の激しい場所に存在 するため, 微分画像においては勾配の大きさの極大值 として現れる。したがって, 微分画像を閾值処理すれ

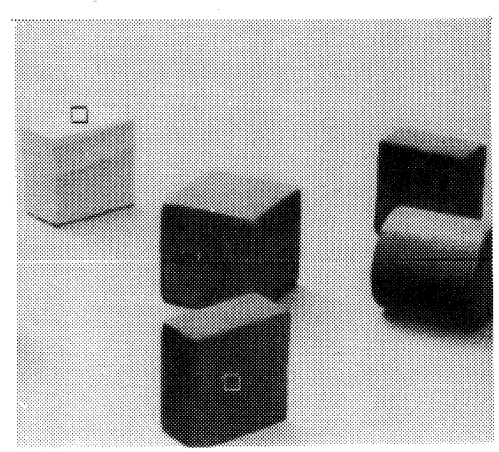

(a) 原画像

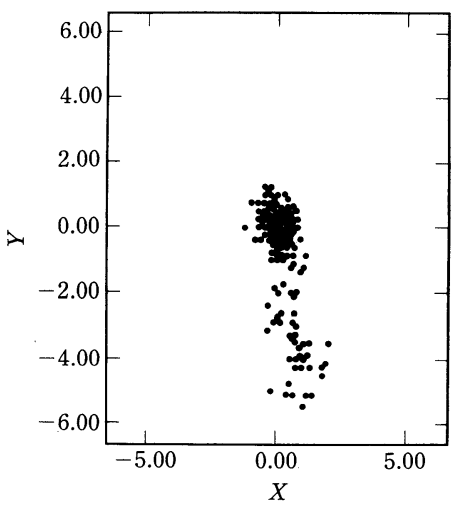

(b) エッジの存在するブロックにおける 微分値の分布

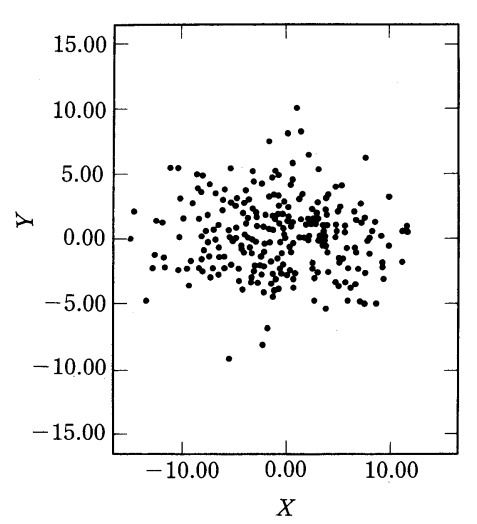

(c) エッジの存在しないブロックにおける 微分値の分布

図 1 微分值の分布

Distribution of gradient magnitude.

(a ) Original image, ( b ) Distribution of gradient magnitude in the edge-existing block, (c) Distribution of gradient magnitude in the non edge-existing block. 
ば，ある程度のエッジは検出される。しかしながら， エッジの強さは相対的なものであり, 周囲に比べては っきりした強さが得られるにもかかわらず，その勾配 の大きさが小さいものも存在する.また，テクスチャ 領域では, ある程度の輝度の振幅が周期的あるいはラ ンダムに存在し, 人間にはエッジとして認められない がその振幅がかなりの大きさになるものもある．この 場合, 微分画像では勾配の大きさが相対的に大きくな ってしまう。

以上のように考えると, エッジを検出するためには ある程度小さな領域に注目し, エッジが認められる領 域と認められない領域とにおいて特徵の差を調べるこ とが必要となってくる.

画像の小領域内の微分值 (Sobel Operator の出力, $x$ 方向, $y$ 方向）の分布を, 重要なエッジの存在する 領域と存在しない領域の 2 つの部分について図 1 に示 す.図 1 (a) は $512 \times 512$ の大きさの原画像であり, 図 1 ( b ) は原画像の中の左上の物体の正方形で囲まれ た領域内の 256 画素の微分値の分布である.また, 図 1 ( c ) は, 中央下の物体の正方形で囲まれた領域内の 256 画素の微分值の分布である.エッジの存在するブ ロックでは，原点付近の大きな集合と同一方向に伸び るまばらな集合との 2 つ集合に分類される。また， エッジの存在しないブロックでは微分值の分布は単峰 状であり，1つの集合とみなすことができる。したが って，この特徴を表すような統計量を用いてエッジの 存在するブロックと存在しないブロックとが分類でき る.また, あるブロックの中に複数のエッジが存在す る場合が考えられるが, 本手法ではブロックの大きさ が充分に局所的であるとあらかじめ仮定しており，そ のブロック内での微分值の大きさが充分に小さい部分 とそれ以外の部分とに分割することができると考えら れる。

\section{3. エッジ検出アルゴリズム}

\section{1 画像のブロック分割}

2 章で述べたように，エッジの存在するブロックと 存在しないブロックではその微分值の分布に違いが見 られる。 そこで, 微分画像を $N \times N$ サイズのブロッ クに分割し, 各々のブロックでのヒストグラムを求め る. 2 次元の分布と 1 次元の分布とで違いはあるが， 微分値の大きさの分布の状態は同等と見ることができ る.すなわち, エッジの存在するブロックにおける微 分値のヒストグラムは，その分布が低い值に大きく集 まる部分と相対的に大きい值を持つ部分とに分かれ る.また，エッジの存在しない部分におけるヒストグ
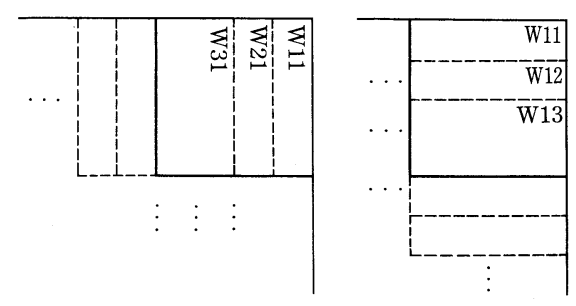

図 2 ブロックのオーバラップ

Overlapping movement of block.

ラムはその分布がはっきりとは分かれることがない.

\section{2 ブロックのオーバラップ}

画像を各ブロックに分割した時に問題となるのは, エッジが各ブロック間の境界付近にある時である。こ の場合, ブロックの境界においてエッジが途切れるこ とがある。したがって、これを避けるためにブロック をオーバラップさせて処理する，すなわち，図2に示 すように, 縦横両方向にブロックサイズの $1 / 4$ だけ移 動して次のブロックを定める。これにより, 境界によ るエッジの途切れはなくなる．もちろん，1画素ずつ ブロックを移動させることにより最も良い結果が得ら れると考えられる。しかしながら, 処理の速度と効率 を合わせて考えるならば，数画素ずつブロックを移動 する方法が良いと考えられる。

\section{3 䦭值決定法}

各ブロック毎に微分值の大きさのヒストグラムの閾 值決定を行う。これには大津の判別分析法㝵を用い る.この手法の概要を述べる.

画像の濃度值のヒストグラムにおいて, 濃度值の集 合を閾值 $t$ で 2 つのラスに分割したと仮定した時, 2 つのクラス間の分離が最も良くなるようにパラメー 夕 $t$ を決めるという考え方に基づいた閾值選択法であ る. 実際には, 2 つのクラスの平均值の分散（クラス 間分散）と各クラスの分散（クラス内分散）の比を最 大にするという基準により $t$ を決める， $t$ の決め方を 以下に示す.

与えられた画像が, $1,2, \cdots, L$ のすべてで $L$ レベル の濃度值をもつとする．ここで, 閾值を $k$ として,$k$ 以上の濃度值を持つ画素と, それより小さな值をもつ 画素の 2 つのグループに分け, それをクラス 1 , クラ ス 2 とする.クラス 1 の画素数を $\omega_{1}(k)$, 平均濃度值 を $\mu_{1}(k)$, 分散を $\sigma_{1}(k)$, クラス 2 の画素数を $\omega_{2}(k)$, 平均濃度值を $\mu_{2}(k)$, 分散を $\sigma_{2}(k)$ と㧍き, 全画素の 平均濃度值を $\mu_{T}$ とおくと, クラス内分散は,

$$
\sigma_{W}{ }^{2}=\omega_{1} \sigma_{1}{ }^{2}+\omega_{2} \sigma_{2}^{2}
$$


クラス間分散は,

$$
\sigma_{B}{ }^{2}=\omega_{1}\left(\mu_{1}-\mu_{T}\right)^{2}+\omega_{2}\left(\mu_{2}-\mu_{T}\right)^{2}=\omega_{1} \omega_{2}\left(\mu_{1}-\mu_{2}\right)^{2}
$$

で与えられる。また, クラス内分散とクラス間分散に は次の基本的な関係が常に成立する.

$$
\sigma_{W}{ }^{2}+\sigma_{B}{ }^{2}=\sigma_{T}{ }^{2}
$$

$\sigma_{T}$ は全分散である.ここでクラス分離度 $\eta(k)$ を導入 し，それを最大にする $k$ を求めればよい.

$$
\eta(k)=\frac{\sigma_{B}{ }^{2}(k)}{\sigma_{T}{ }^{2}}
$$

すなわち, $\eta(k)$ を最大にするには $k$ を変化させて $\sigma_{B}{ }^{2}$ を最大にする $k$ を求めればよい.

ところが, 微分画像の画素值は実数值をとる. しか も，各ブロック毎にその範囲はさまざまである．ブロ ック内の画素值のとる範囲が小さければ, 閾値決定を 正しく行うことができなくなる．したがって，画素值 を 10 倍にして四捨五入で整数化する. 画素值にアフ イン変換を施しても, 閾値最適化に用いられるクラス 分離度は不変である ${ }^{8)}$.

整数化した画素值のヒストグラムを求め, 閾值決定 を行った後, 閾值をもとの画素值のレベルに逆変換す る。

\section{4 ブロックの分類とエッジ要素の検出}

エッジを含むブロックと含まないブロックに分類す る手法について述べる。ここでは，ひとつの基準を用 いてエッジを含むブロックであるかないかを分類す る.それは閾值決定時に算出されるクラス分離度であ る.この基準に対して閾值を求め，あるブロックに対 してクラス分離度が閾值より大きい場合に，そのブロ ックはエッジが存在するブロックであると判定する．

ヒストグラムに闇値処理を行った場合, ヒストグラ ムは 2 つのクラスに分かれる. エッジの存在するブロ ックにおけるヒストグラムでは，2 2 つクラスの分離 度が大きい。 また，エッジの存在しないブロックにお いては，2つのクラスの分離度が小さい．このことを 利用して，画像の各ブロックを分類しようとするもの である。

この基準は，画像の各ブロックにおける微分值の閾 值を決定する時に同時に求められる．各々のブロック で求められたクラス分離度の集合を閾値処理すること によって, ブロックをエッジの存在するブロックと存 在しないブロックとに分類する.

クラス分離度についてはその定義により，0 $0 \leq \eta \leq 1$ の值をとるため有界である.

ブロックの分類方法は, 画素值の閾值決定のときと 同じく判別分析法を用いる。ここで，ヒストグラムを
求める時にノイズの影響を避けるため, 各ブロックの クラス分離度を用いるかわりに次に示す值を用いる。

いま，ブロック $W_{i j}$ がクラス分離度 $\eta_{i j}$ をつもの とする．また，ブロックの集合 $G$ を次のように定義 する.

$$
G=\left\{W_{k l} \mid i-1 \leq k \leq i+1, j-1 \leq l \leq j+1\right\}
$$

すると, 集合 $G$ の各要素がもつ $\eta$ の集合 $E$ は次のよ うに表すことができる。

$$
E=\left\{\eta_{k l} \mid i-1 \leq k \leq i+1, j-1 \leq l \leq j+1\right\}
$$

$\eta_{i j}$ を集合 $E$ の最大值 $\eta_{\max }$ に置き換えてクラス分離 度のヒストグラムを求める。

クラス分離度は 1 以下の正数值であるので, これを 100 倍して整数化し，ヒストグラムを求める。そし て, 閾值 $\eta_{t}$ を決定したのち, 各ブロック $W_{i j}$ の $\eta_{i j}$ と比較し, エッジの存在するブロックとエッジの存在 しないブロックに分類する．

エッジの存在するブロックに対して微分画像の画素 值の閾值処理を行う. 閾値 $t$ 以下の值をもつ画素の值 は 0 で置換される。また，1つの画素は複数のブロッ クに含まれている，この場合, エッジが存在するブロ ックに分類されたブロックの閾值のうちの最小値を閾 值として画素を閾値処理する，このようにして，エッ ジ要素が検出される.

\section{5 細線化処理}

3.4 節ではエッジ要素の検出を行う処理を述べた. この処理によって, エッジである確率の高い画素であ る微分の極大值と, その付近が同時に検出される。し たがって, 細線化が必要となる。この処理にはNonmaxima Suppression を用いる.この方法はエッジの 方向に関して垂直な方向に隣接する 2 要素との微分值 の大小関係を調べ, 最も大きい值をもつものを残し， 小さい 2 要素を除去するものである。また，細線化を 行った後, 孤立したエッジを除去する．

\section{4. 実験および考察}

\section{1 実験結果}

本エッジ検出アルゴリズムを用いて, サイズが $512 \times 512$ の幾つかの画像について処理をした結果を 図3～図 5 に示す．いずれも，(a) は入力画像，(b) は出力エッジ画像，（c）は比較のために単一閾值で微 分画像を閾值処理してエッジ検出した画像である．画 像の微分には種々の微分法が存在するので, 当然, 微 分法によりその結果が異なる場合が出てくると考えら れる. 特に, 濃度変化の小さいエッジの存在する部分 ではノイズの影響が大きく現れる，このため，本手法 では，ノイズの影響を最も受けにくい微分法のひとつ 


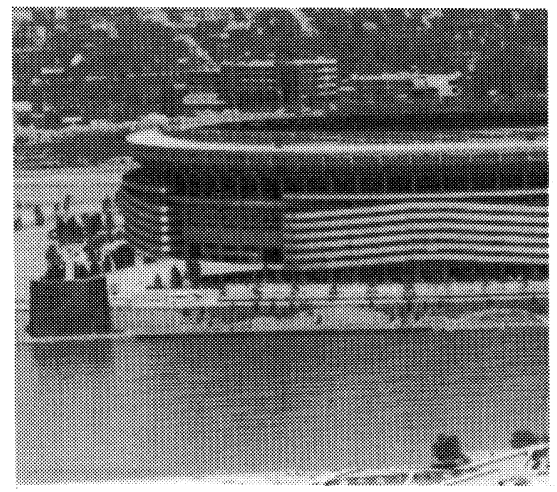

(a) 入力画像

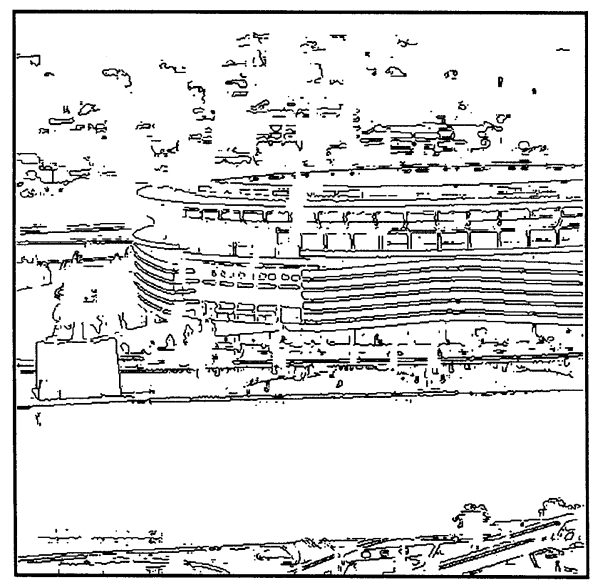

(b) 出力画像

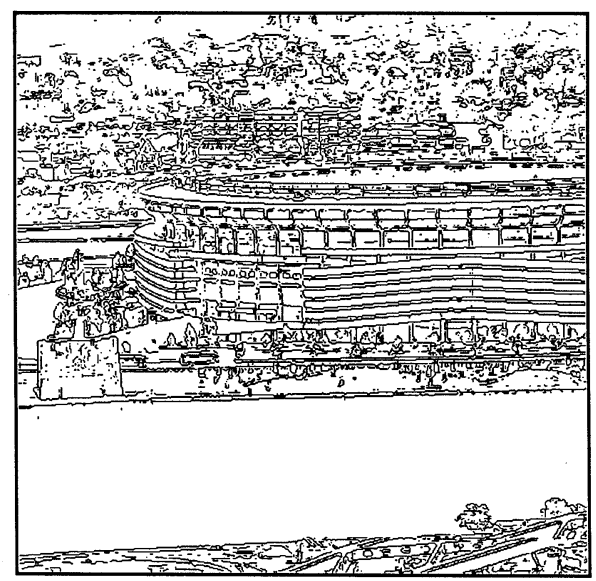

(c) 単一閾値 $(=10)$ でエッジ検出をした画像

図 3 実験結果 (CITY 画像)

Experimental result. (CITY image)

(a) Input image, (b) Output image, (c) Output image obtained by uniform thresholding. The threshold value is 10 .

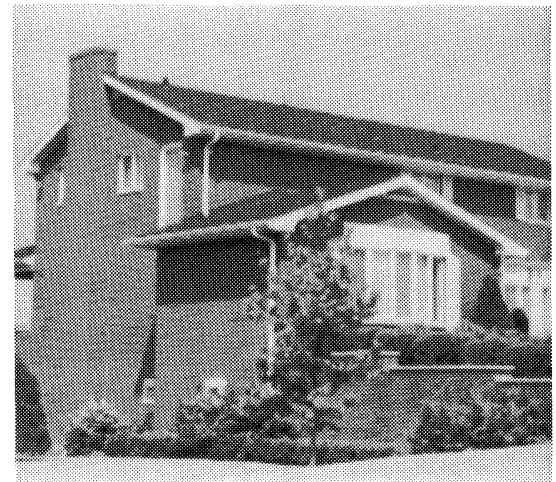

(a) 入力画像

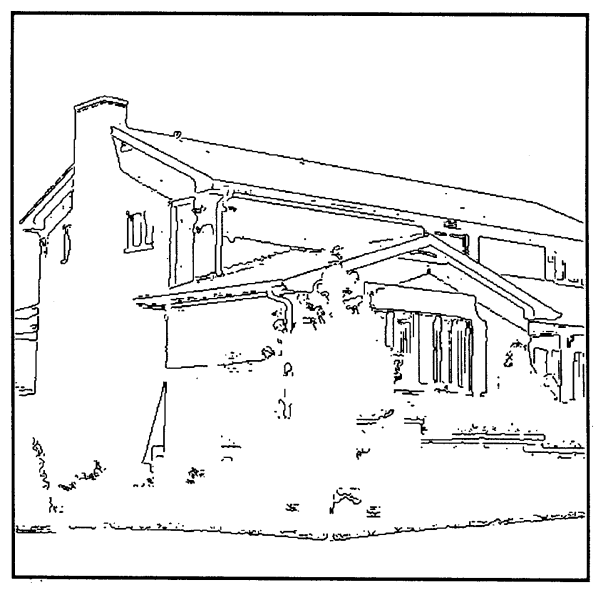

(b) 出力画像

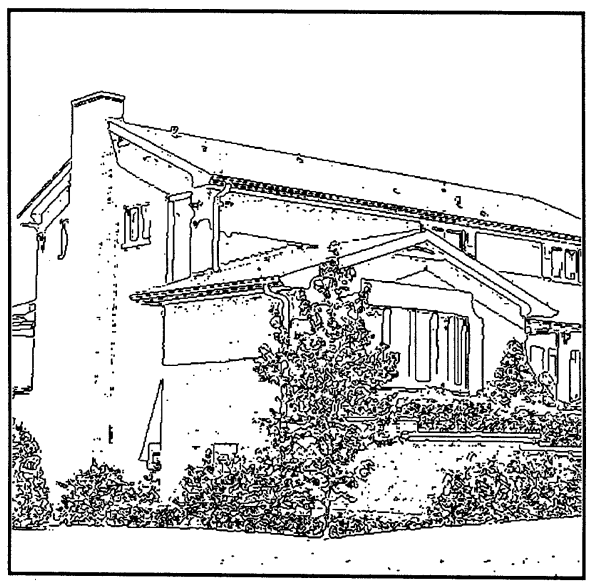

(c) 単一閾值 $(=10)$ でエッジ検出をした画像

図 4 実験結果 (HOME 画像)

Experimental result. (HOME image) (a Input image, (b) Output image, (c ) Output image obtained by uniform thresholding. The threshold value is 10 . 


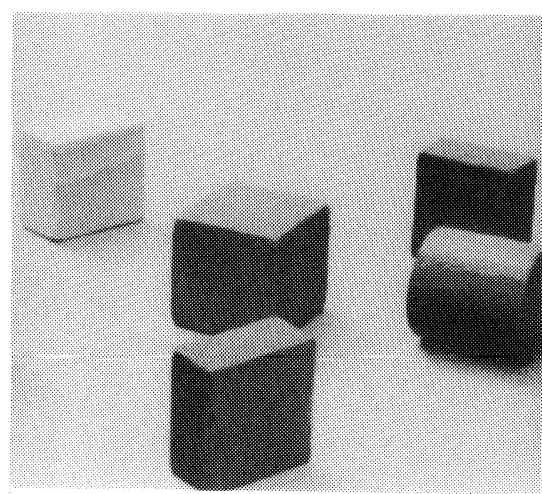

(a) 入力画像

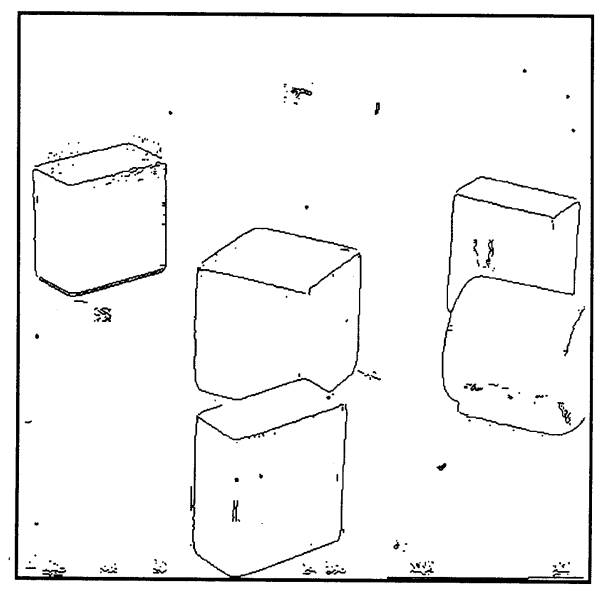

(b) 出力画像

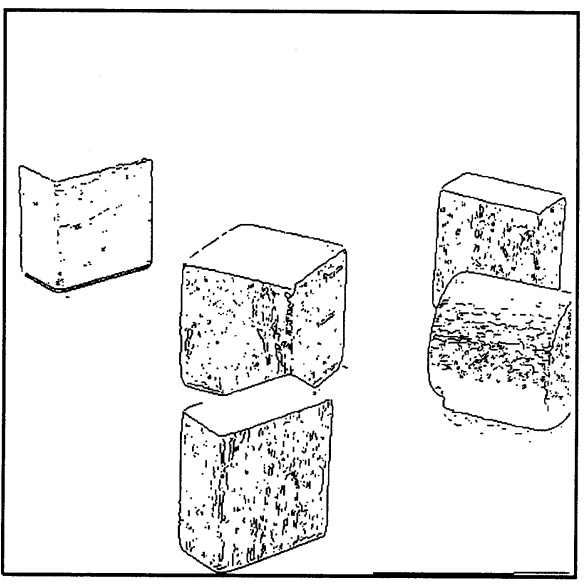

(c) 単一閾値 $(=10)$ でエッジ検出をした画像

図 5 実験結果 (TOY 画像)

Experimental result. (TOY image) (a) Input image, (b) Output image, (c) Output image obtained by uniform thresholding. The threshold value is 10 .
である Sobel Operator を用いた。また，ブロックの サイズは種々の実験の結果, 最も良いと考えられる $12 \times 12$ を採用した。

CITY の画像（図 3 )では，本論文で述べた手法は正 面の建物のみをよく抽出している：単一閾值で処理を した画像では，正面の建物とともに，背景の斜面の部 分のノイズがたくさん検出されている.次の例は HOME の画像（図 4 ）の場合である. 両手法とも，家 と背景の境界, 空, 屋根などがよく検出されている. また，本論文で述べたアルゴリズムを用いた結果は木 のテクスチャによるノイズを検出しておらず，物体の 輪郭を構成するエッジのみをよく検出している。これ は，木のテクスチャ部分の微分值を閾值決定した際の 2 つのクラスの分離度が小さく，エッジの存在しない 部分であると判定されるのに対し，物体の境界部分を 構成する部分では，その分離度が大きくエッジの存在 する部分と判定されるからである．最後の例は TOY の画像（図 5 ）である。この場合には，単一閾值を用 いた方法では，画像中左の物体の輪郭が失われてい る.また，各物体の内部のテクスチャによるノイズが 多く検出されている．それに対して，本論文のエッジ 検出アルゴリズムを用いた結果では，重要なエッジは よく検出されている。

\section{2 考 察}

本論文におけるエッジ検出の目的は，テクスチャな どのノイズはエッジとして検出せずに真の境界のみを エッジとして検出することである．そのための方法と して, 微分值の分布に基づいた閾值処理を行うアルゴ リズムを用いている．このため, 微分の極大值が小さ い場合でもエッジとして検出される．また，極大值が 大きい場合でもその付近の微分值の分布により, エッ ジでないと判断される場合もある。こういう意味で, 物体と物体, 背景と物体との境界のエッジを抽出する ことにおいて，単一の閾值を用いた手法などに比較し てその有効性が示された。 また本エッジ検出アルゴリ ズムは，原画像を直接微分し，ある程度以上の連続性 と一定の方向性を持った微分值の極大值をエッジとし て出力するので, エッジの位置は正確に出力され, ガ ウシアンフィルタを用いて画像をぼかしてからエッジ を検出する手法のように，エッジの位置を正確に求め る問題は起こらない。

\section{5.むす び}

微分值の局所的な分布に基づいたエッジ検出アルゴ リズムを提案し，実験および考察を加えた。このアル ゴリズムは, 多くの関連研究にあるのとは異なり，画 
像の平滑化処理を行わずにテクスチャによるノイズな どを抑圧しょうとするものである．画像を小さなブロ ックに分割し, 局所的な特徵, すなわち, エッジの存 在する部分とエッジの存在しない部分の微分值の分布 に基づいて, エッジの存在するブロックと存在しない ブロックに分類し，エッジの存在する部分に対して閾 值処理をすることによりエッジ要素を検出する. 得ら れたエッジ要素を滑らかな細線に処理するために Nonmaxima Supperssion を用いる.その結果は, テ クスチャによるノイズを充分に抑制し，重要なエッジ をよく検出していることがわかり，本手法の有効性が 示された．特に従来の手法では検出されてしまう木久 や表面のテクスチャによるノイズなどを抑制するには 非常に有効である．本手法による結果は，例えばエッ ジ追跡によって, より連続したエッジを得, さらに多 角形近似などの高レベル処理を行うなどの画像解析に 適用できる。

\section{〔参考 文 献〕}

1) D. H. Ballard and C.M. Brown: "Computer Vision", Prentice-Hall (1982)

2) J. O. Eklundh, T. Elfving, and S. Nyberg: "Edge Detection Using the Marr-hildreth Operator with Different Sizes", In 6th ICPR, Munich, pp. 1109-1112 (1982)
3) A. Rosenfeld and M. Thurston: "Edge and Curve Detection for Visual Scene Analysis", IEEE Trans. Comput., 20 (1971)

4) J. F. Canny: "A Computational Approach to Edge Detection", IEEE Trans. Pattern Anal. \& Mach. Intel., 8, pp. 679-698 (Nov. 1986)

5) R. Deriche: "Using Canny's Criteria to Derive a Recursively Implemented Optimal Edge Detector", Int. J. Comput. Vision, pp. 167-187 (1987)

6) F. Bergholm: "On the Content of Information in Edges and Optical Flow", $\mathrm{PhD}$ thesis, University of Stockholm (1989)

7）高橋, 高木： “高レベル処理に適したエッジ追跡”，信学技報 PRU90-84, 90, 305, pp. 23-30 (Nov. 1990)

8）大津：“判別および最小 2 乗規準に基づく自動しきい值選定 法”, 信学論, J63-D, pp. 349-356（1980）

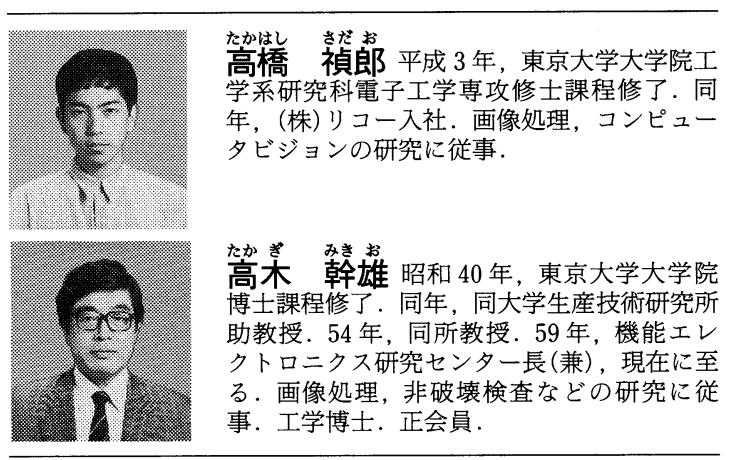

